\title{
EARTH QUAKE RESPONSE OF DIFFERENT SHAPES OF MIVAN WALL TALL BUILDINGS
}

\author{
Sajeet.S.B ${ }^{1}$, Supreeth S Gowda ${ }^{2}$ \\ ${ }^{1}$ Structural Engineer, Prasad Consultant, Bangalore, Karnataka, India \\ ${ }^{2}$ Post Graduate Student In Structural Engineering, BGS, Bangalore, Karnataka, India
}

\begin{abstract}
In recent times due to globalization, the construction industry has started focusing on new innovative ways of working. The construction industry has started adopting new technologies and approaches in order to increase the overall efficiency of the project. The "aluminum formwork systems" which is also called as Mivan wall System is one such new technology which has been used extensively across the world. . MIVAN WALL technology is suitable for constructing large number of houses within short time using room size forms. In this system of formwork construction, cast-in-situ concrete wall and floor slabs are casted monolithically in one continuous pour. In the present work, the Different shapes of Mivan wall building which is irregular in shape is analyzed by Response Spectrum Method further the investigation is carried to know the contribution of different shapes of Mivan wall building to lateral strength and lateral stiffness of the high rise building. Along with this the comparison has been carried out between different shapes of Mivan wall building.
\end{abstract}

Key Words: Mivan wall, Tall Building and Aluminum formwork

\section{General}

Construction is one of the noteworthy segments of Indian economy. It is also an integral part of the development. Today, in terms of urban population, India is the second largest in the world. This development leads to amplified demand for housing. To overcome this problem, India should plan for acquirement of land and speedy creation of housing units at greater extent.

There is rising awareness today that the speed of construction desires to be set superior importance particularly for huge housing projects. This is crucial for the sooner business of equipment investments.

There is a need to reduce the housing cost to achieve the national objective of creating a large standard. Luckily, certain progressive technologies providing quicker construction are already available in the country. For e.g. autoclaved blocks, Prefabrication, tunnel formwork, and aluminum formwork (MIVAN Technology) of construction etc.

The calamitous effects of historical earthquakes on life and properties have amplified the necessity for an assessment of the conventional lateral load resisting systems. It has lead us to implement advanced and improved lateral load resisting systems for operative and effective moderation of earthquake forces

\subsection{Objectives}

The objectives of this study can be listed as follows

$>$ To study the earthquake response of Tall irregular Mivan wall building by response spectrum analysis.
$* * *$

$>$ To study the earthquake response of different shapes of Tall irregular Mivan wall building by response spectrum analysis.

$>$ To compare the earthquake response of different shapes of Tall irregular Mivan wall building.

\subsection{Present Study}

Even though reinforced concrete walled structures are madeup to execute well in the incident of an earthquake, their seismic behavior is always of concern. Several such examples of reinforced concrete wall failures may be found during past earthquakes. Existence of openings, irregularities, rare slenderness and absence of proper ductile reinforcement are probable to cause failures in reinforced concrete walls. Codal provisions are of critical shortage for the seismic resistant design of reinforced concrete wall buildings. Henceforth, it is proposed to learn the seismic behavior of reinforced concrete wall constructions in this present work.

Due to the functional requirement of the buildings, irregularity in structures is unavoidable in the structural design of multistoried buildings. Horizontally irregular buildings are analyzed for their stability in this project.

As directed in IS 1893:2002, multistoried horizontally irregular buildings were modeled in program ETABS 2013. Irregular plan like L - shape, $\mathrm{H}$ - shape and C - shape are taken for this study. Each structure is modeled for 10 storey. Each model has the same plan area. Analysis is done for Imposed loads, Dead loads and Earthquake load as per IS 1893: 2002. Combinations of loads are driven as per the appropriate Indian Standard codes. For the assessment, parameters like time period, frequency, storey drift ratio, 
displacement, and base shear are used. Results are tabulated and plotted for time period, frequency, storey drift ratio, displacement, and base shear for different shapes. The results were discussed by comparing the above three shapes to obtain the shape which is best suitable for the earthquake resistance.

\section{RESPONSE SPECTRUM ANALYSIS}

Without the need of time history analysis, the procedure to compute the peak response of structure during the earthquake directly from the earthquake response spectrum is called response spectrum analysis.

Response spectrum is a plot of maximum response of a SDF for various value of the period for a given input. The IS1893 gives an average Response spectrum can be employed in earthquake resistant design.

\subsection{Strucural Model}

For this study, building with ten storey is considered. The Area of all the buildings are exactly same i.e $672 \mathrm{~m}^{2}$. The structural models have the same story height of $3 \mathrm{~m}$ and have a uniform mass distribution over their height. Building plan is shown is below fig.3.2.a

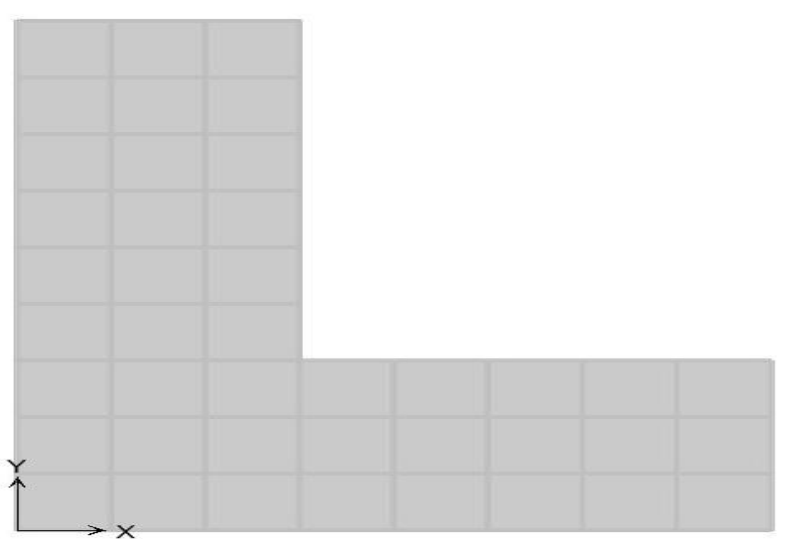

Fig.3.2.a L SHAPE MW Building Plan

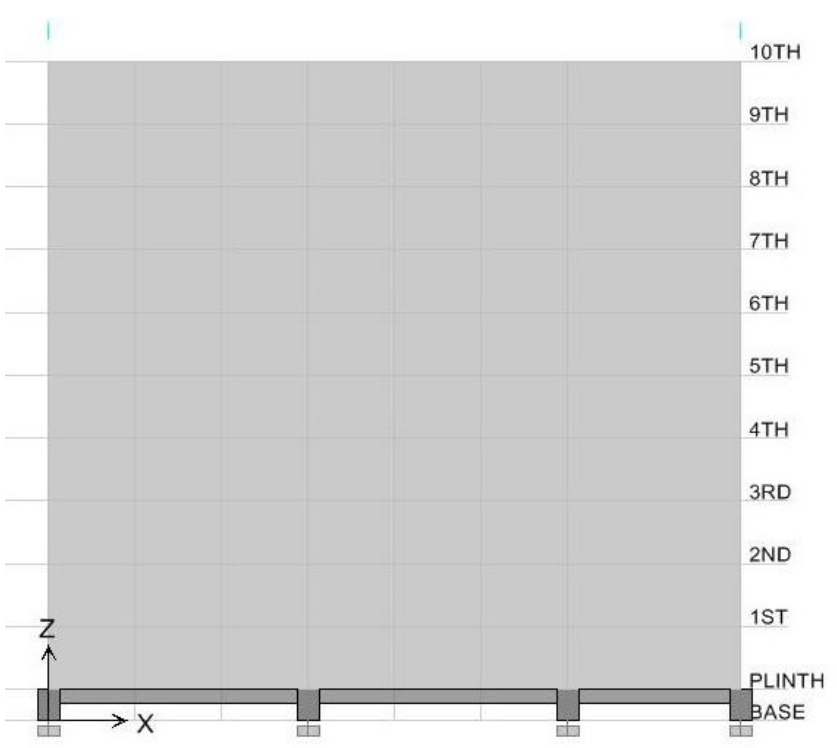

Fig.3.2.b L SHAPE MW Building Elevation

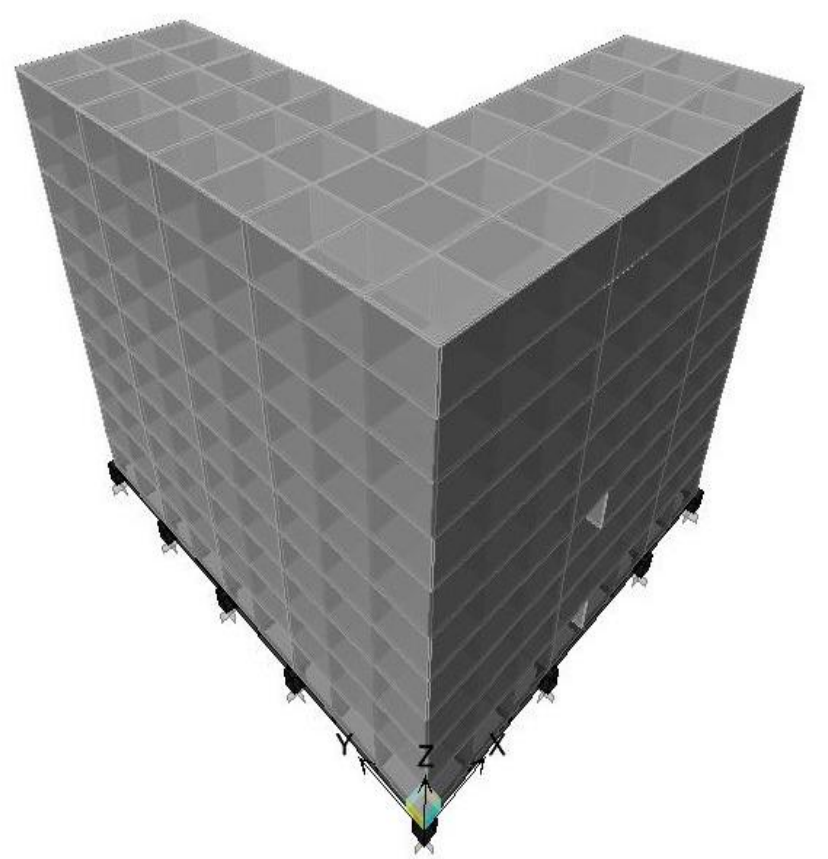

Fig.3.2.c L SHAPE MW 3D View

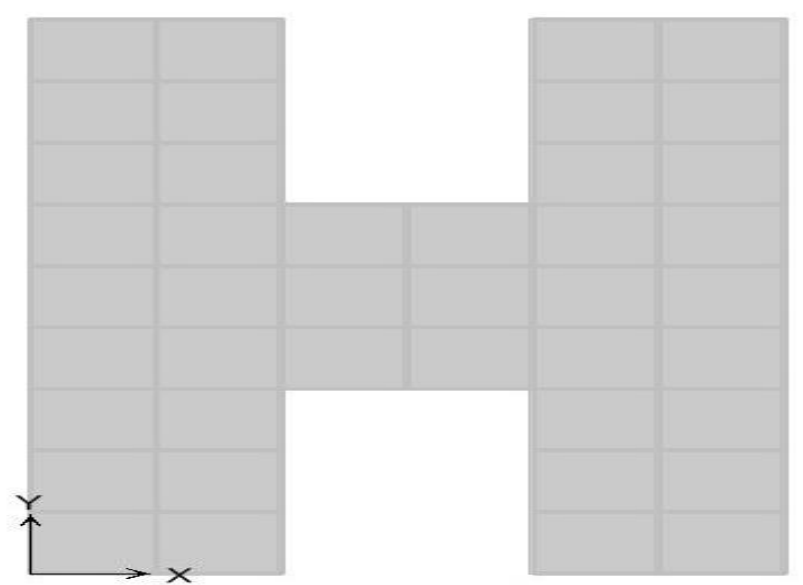

Fig.3.2.a H SHAPE MW Building Plan

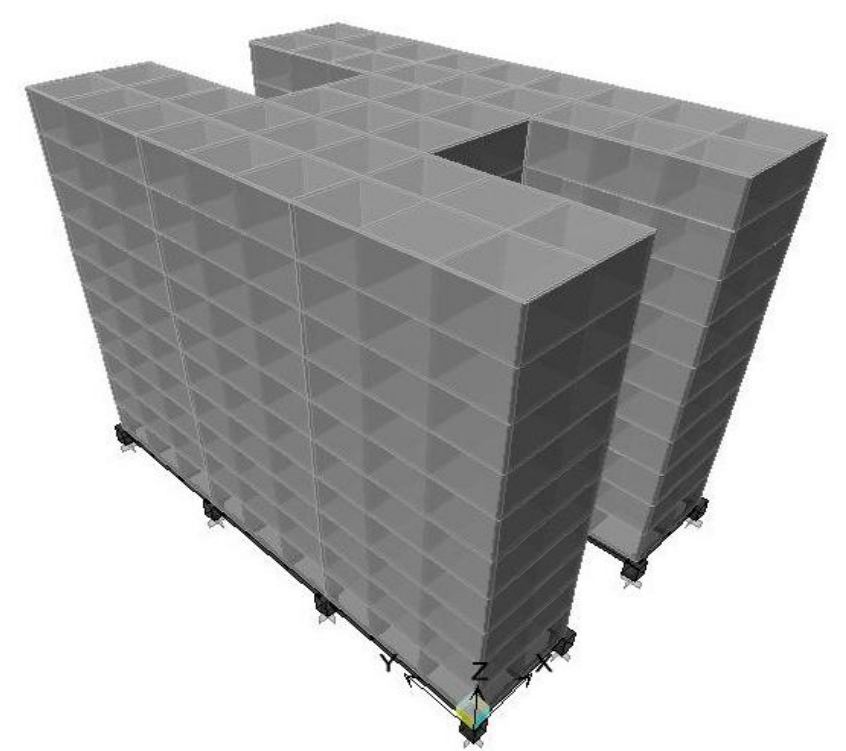

Fig.3.2.b H SHAPE MW 3D View 


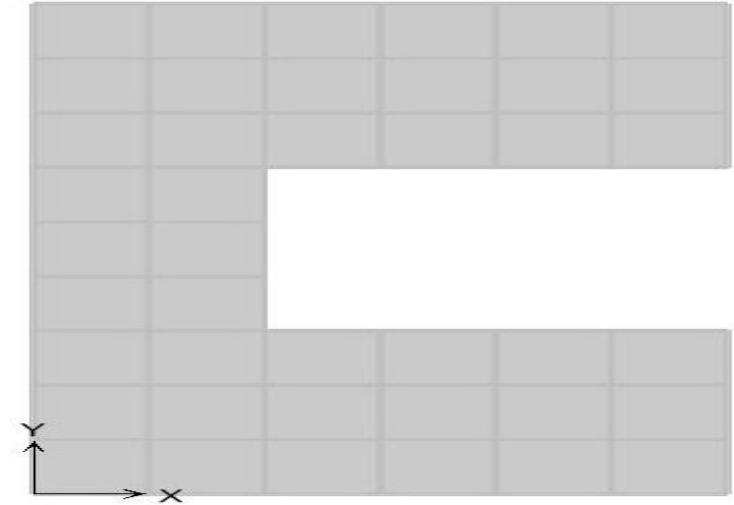

Fig.3.2.a C SHAPE MW Building Plan

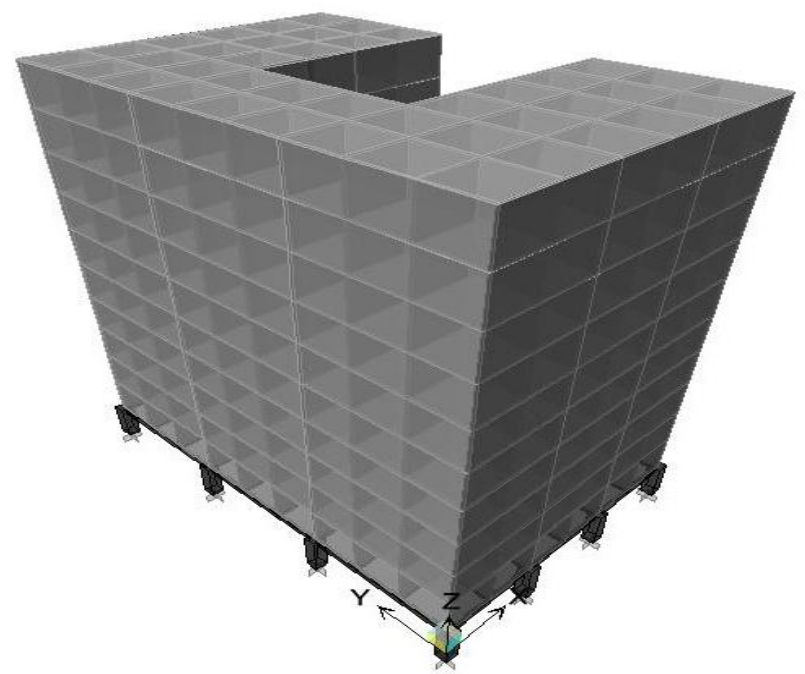

Fig.3.2.c C SHAPE MW 3D View

\subsection{Input Details}

Table 1-Structural Sections Detail

\begin{tabular}{|l|l|l|}
\hline \multicolumn{2}{|l|}{ COLUMN SIZES $(\mathrm{mm})$} & BEAM SIZES $(\mathrm{mm})$ \\
\hline STORY & ALL MODELS & ALL MODELS \\
\hline PLINTH & $1000 X 1000$ & $200 X 650$ \\
\hline
\end{tabular}

Table 2-Seismic Loading Zone As Per Is:1893

\begin{tabular}{|l|l|}
\hline DETAIL & VALUE \\
\hline $\mathrm{R}$ & 3 \\
\hline $\mathrm{I}$ & 1 \\
\hline $\mathrm{Z}$ & .10 \\
\hline $\mathrm{Sa} / \mathrm{G}$ & Type2 \\
\hline
\end{tabular}

\section{$\mathrm{Z}=$ Zone $\quad \mathrm{Sa} / \mathrm{g}=$ Soil type II,}

$\mathrm{R}=$ response reduction factor $\mathrm{I}=$ Importance factor
Table 3-Material Properties

\begin{tabular}{|l|l|}
\hline $\begin{array}{l}\text { MODEL TYPE } \\
\text { MATERIAL PROPERTIES }\end{array}$ & ALL Model \\
\hline Column / Wall & M45 \\
\hline Beam & M25 \\
\hline Slab & M25 \\
\hline
\end{tabular}

Density of concrete: $25 \mathrm{KN} / \mathrm{m} 3$

Slab thickness: $125 \mathrm{~mm}$

\subsection{Static Load Assignment}

The loads considered are

Dead Load, Live Load, Floor Finish, and Earth Quake Load. All models consist of these loads.

Dead Load: The dead load of the structure is obtained from of IS 875 - Part 1 - 1987, Table 1, Page 8 . Value for unit weight of reinforced concrete varies from $24.80 \mathrm{kN} / \mathrm{m}^{3}$ to $26.50 \mathrm{kN} / \mathrm{m}^{3}$. From the table1, the unit weight of concrete is taken as $25 \mathrm{kN} / \mathrm{m}^{3}$. The software has a inbuilt DL calculator Self-weight of the structural elements

Floor finish $=2 \mathrm{kN} / \mathrm{m}^{2}$

Imposed Load: The imposed load on the floor is obtained from IS 875 (Part 2) - 1987, Table 1. On the floor of the building the uniformly distributed load is assumed to be 4.0 $\mathrm{kN} / \mathrm{m}^{2}$.

On roof $1.5 \mathrm{kN} / \mathrm{m}^{2}$, and

On floors $4.0 \mathrm{kN} / \mathrm{m}^{2}$

Earth Quake Load: The structure is assumed to be as per IS 1893 - 2002 in Zone-II. So the zone factor is taken as per Table 2 of IS 1893 - 2002. The 5\% damping is assumed for concrete as per IS 1893-2002(Table 3). 1 is taken as Importance factor as per Table 6 of IS $1893-2002$.

Zone II, Soil type II, Importance factor $=1$

Response Reduction Factor, in this values of $\mathrm{R}$ are defined $. R=3$ is used .

Load combinations: The load combinations is obtained from page no13, clause 6.3.1.2 of. IS $1893-2002$.

$\mathrm{DLEQX}=(1.2 \mathrm{DL}+1.2 \mathrm{LL}+1.2 \mathrm{SPECX})$

$\mathrm{DLEQY}=(1.2 \mathrm{DL}+1.2 \mathrm{LL}+1.2 \mathrm{SPECY})$

Table 4-Analysis Input

\begin{tabular}{|l|l|}
\hline TYPES OF MODELS & ALL MODDL \\
\hline R VALUE & $\mathrm{R}=3$ \\
\hline Function input & 0.1 \\
\hline spectrum case name & $\mathrm{spec} 1$ \\
\hline structural and function damping & 0.05 \\
\hline model combination & $\mathrm{CQC}$ \\
\hline directional combination & $\mathrm{SRSS}$ \\
\hline input response spectra & $9.81 / 2 * 3$ \\
\hline eccentricity ratio & 0.05 \\
\hline
\end{tabular}




\section{ANALYSIS AND RESULTS}

\subsection{Frequency and Time Period}

The value of $\mathrm{T}$ depends on the building flexibility and mass; more the flexibility and mass, the longer is the period.

From below Tables.., the maximum time period is in TYPE 3 model and minimum time period is in TYPE 1 model. Therefore one can say that TYPE 1 model has more flexibility and mass when compared to other models.

Table 5- Time perioed vs modes

\begin{tabular}{|l|l|l|l|}
\multicolumn{1}{c}{ MODES } & \multicolumn{1}{c}{ TP-T1 } & \multicolumn{1}{l|}{ TP-T2 } & \multicolumn{1}{l|}{ TP-T3 } \\
\hline $\mathbf{1}$ & 0.186267 & 0.199968 & 0.351805 \\
\hline $\mathbf{2}$ & 0.174821 & 0.153098 & 0.335427 \\
\hline $\mathbf{3}$ & 0.144164 & 0.150553 & 0.279735 \\
\hline $\mathbf{4}$ & 0.058886 & 0.062286 & 0.102926 \\
\hline $\mathbf{5}$ & 0.055945 & 0.050034 & 0.099046 \\
\hline $\mathbf{6}$ & 0.04564 & 0.048869 & 0.065811 \\
\hline $\mathbf{7}$ & 0.026984 & 0.029287 & 0.036255 \\
\hline $\mathbf{8}$ & 0.025986 & 0.02577 & 0.034335 \\
\hline $\mathbf{9}$ & 0.023569 & 0.023633 & 0.029871 \\
\hline $\mathbf{1 0}$ & 0.017752 & 0.019124 & 0.022494 \\
\hline $\mathbf{1 1}$ & 0.017288 & 0.017332 & 0.02194 \\
\hline $\mathbf{1 2}$ & 0.016175 & 0.016119 & 0.020103 \\
\hline
\end{tabular}

Table 6- frequency vs modes

\begin{tabular}{|l|l|l|l|}
\hline MODES & FR-T1 & FR-T2 & FR-T3 \\
\hline 1 & 5.368637 & 5.0008 & 2.842484 \\
\hline 2 & 5.720137 & 6.531764 & 2.981275 \\
\hline 3 & 6.936544 & 6.642179 & 3.574812 \\
\hline 4 & 16.98197 & 16.05497 & 9.715718 \\
\hline 5 & 17.8747 & 19.98641 & 10.09632 \\
\hline 6 & 21.9106 & 20.46287 & 15.19503 \\
\hline 7 & 37.059 & 34.14484 & 27.5824 \\
\hline 8 & 38.48226 & 38.80481 & 29.1248 \\
\hline 9 & 42.42861 & 42.31371 & 33.47729 \\
\hline 10 & 56.33168 & 52.29032 & 44.4563 \\
\hline 11 & 57.84359 & 57.69675 & 45.57885 \\
\hline 12 & 61.8238 & 62.03859 & 49.74382 \\
\hline
\end{tabular}

\subsection{DISPLACEMENT (mm)}

As it can be seen from below figures, the displacement of the stories of structures is reduced by developing a TYPE 1 model. In addition to the results of all models the maximum displacement is in TYPE 3 model and minimum displacement is in TYPE1 model. Furthermore the graph shows that there has been steady increase in the amount of displacement of stories over the height.

According to this work, the reduction of displacement of stories is due to increase of stiffness of structure as well as decrease of velocity and acceleration of structure. In other words by creating the TYPE 1 model, the response of structure such as velocity and acceleration can be reduced and it is the cause of reduction of displacement.

On Observing, displacements at all the storey in the TYPE 1 model is less than those in Other model. Here as one can see displacements lowest in bottom stories, very high at the upper stories.

The displacement is of interest with regard to structural stability, strength and human comfort. The displacement of TYPE1 model is less than the other model. It means that Structure is more stable

Chance of Structural Strength reduction is less. Human comfort is good.

\section{EARTH QUAKE IN X-DIRECTION}

\begin{tabular}{|l|l|l|l|}
\hline STOREY & UX-T1 & UX-T2 & UX-T3 \\
\hline $10 \mathrm{TH}$ & 0.3163 & 0.6963 & 1.4196 \\
\hline 9TH & 0.3062 & 0.6515 & 1.3791 \\
\hline $8 \mathrm{TH}$ & 0.2925 & 0.6022 & 1.3334 \\
\hline $7 \mathrm{TH}$ & 0.2755 & 0.5484 & 1.2831 \\
\hline $6 \mathrm{TH}$ & 0.2557 & 0.4907 & 1.2287 \\
\hline 5TH & 0.2335 & 0.4299 & 1.1712 \\
\hline 4TH & 0.2096 & 0.3674 & 1.1116 \\
\hline 3RD & 0.1849 & 0.3047 & 1.0513 \\
\hline 2ND & 0.1598 & 0.2431 & 0.9906 \\
\hline 1ST & 0.1363 & 0.1858 & 0.9331 \\
\hline GF & 0 & 0 & 0 \\
\hline BASE & 0 & 0 & 0 \\
\hline
\end{tabular}

EARTH QUAKE IN Y-DIRECTION

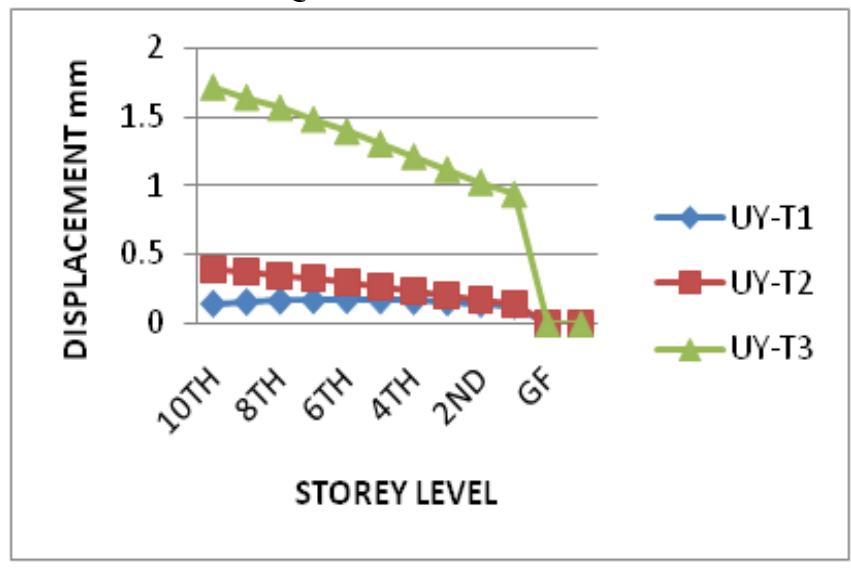

Fig 4: Displacement-y vs Storey level

\subsection{Story Drift Ratio}

It is the displacement of one level relative to the other level above or below.

The building may collapse due to different response quantities. For eg., at local levels such as strains, curvatures, rotations and at global levels such as interior story drifts. 
Individual stories may exhibit excessive lateral displacement. Therefore it can be concluded that by decreasing the story drifts of structure, the probability of collapse of the building can be reduced. To do that, as it is mentioned, TYPE 1 model can play a significant rule to reduce response of structure.

On Observing, storey drift ratios at all the stories in the TYPE 1 model are less than those in Other model. Here as one can see the storey drift ratio is very low in bottom stories, very high at the middle stories and finally decreases towards the upper stories.

\section{EARTH QUAKE IN X-DIRECTION}

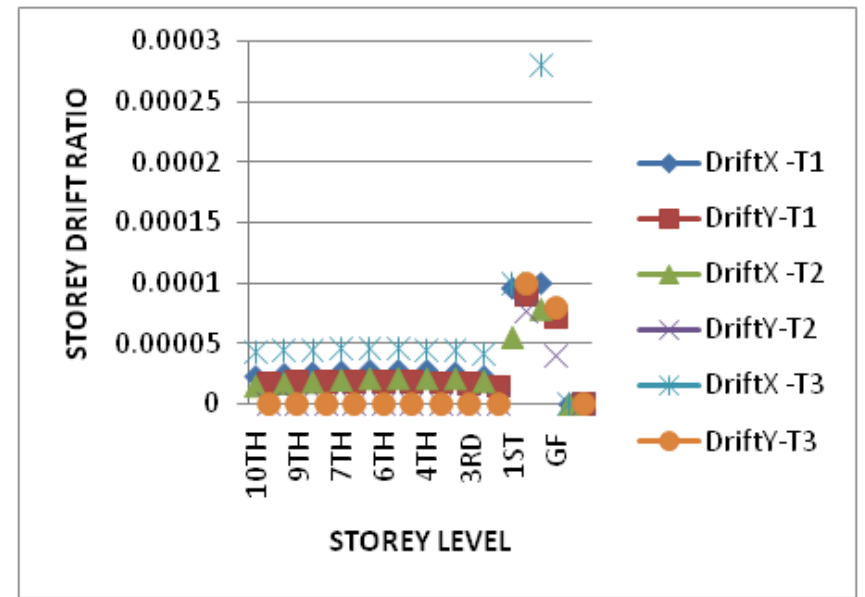

Fig 5: storey drift ratiot-x vs Storey level

\section{EARTH QUAKE IN Y-DIRECTION}



Fig 6: storey drift ratiot-y vs Storey level

\subsection{STORY SHEAR (Kn)}

It is the sum of design lateral forces at all levels above the storey under consideration.

As it can seen from below figures, the max story shear is in TYPE 1 model and minimum story shear in TYPE 3 model. Furthermore the graph shows that there has been steady decreasing in the amount of story shear over the height. In all models, the story shear at the base is more and at the top story shear is less. But when we compare All models, the minimum story shear is in TYPE1 model and maximum is in TYPE 3 model.

\section{EARTH QUAKE IN X-DIRECTION}

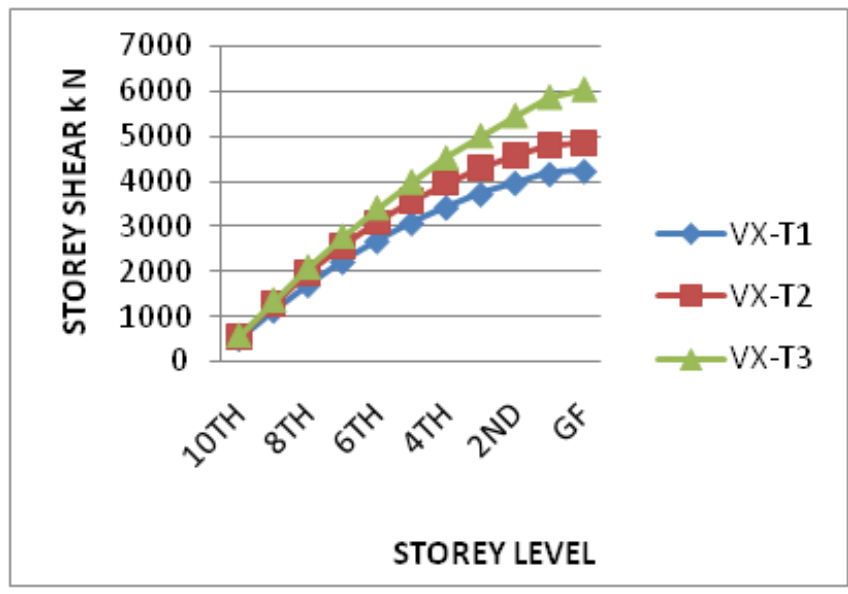

Fig 7: storey shear-x vs Storey level

\section{EARTH QUAKE IN Y-DIRECTION}

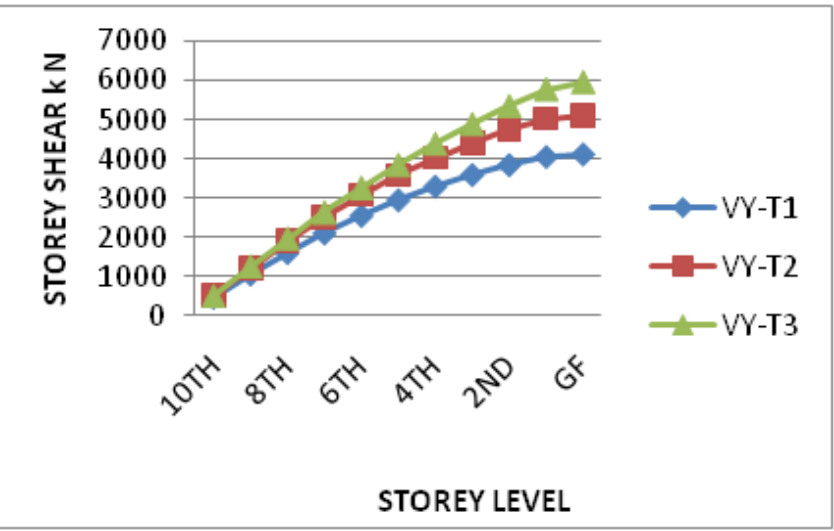

Fig 8: storey shear-y vs Storey level

\section{BASE SHEAR, DISPLACEMENT}

Table 5-Avearge Reduction

\begin{tabular}{|c|c|c|c|}
\hline $\begin{array}{l}\text { KIND OF } \\
\text { RESPONSE } \\
\text { OF } \\
\text { STRUCTUR } \\
\text { E IN X X } \\
\text { DIRECTION }\end{array}$ & $\begin{array}{l}\text { TYPES OF } \\
\text { MODEL }\end{array}$ & $\begin{array}{l}\text { MAX } \\
\text { VALU } \\
\text { E }\end{array}$ & $\begin{array}{l}\text { AVEARGE } \\
\text { REDUCTION } \\
\%\end{array}$ \\
\hline & & & \\
\hline $\begin{array}{l}\text { DISPLACE } \\
\text { MENT(MM) }\end{array}$ & $\mathrm{T} 2$ & 0.6963 & 77.7 \\
\hline & T3 & 1.4196 & - \\
\hline $\begin{array}{l}\text { KIND OF } \\
\text { RESPONSE } \\
\text { OF } \\
\text { STRUCTUR } \\
\text { E IN Y- } \\
\text { DIRECTION }\end{array}$ & $\begin{array}{l}\mathrm{R} \\
\text { VALUUE }\end{array}$ & $\begin{array}{l}\text { MAX } \\
\text { VALU } \\
\text { E }\end{array}$ & $\begin{array}{l}\text { AVEARGE } \\
\text { REDUCTION }\end{array}$ \\
\hline & $\mathrm{T} 1$ & 0.1389 & 64.6 \\
\hline $\begin{array}{l}\text { DISPLACE } \\
\text { MENT(MM) }\end{array}$ & $\mathrm{T} 2$ & 0.3928 & 91.9 \\
\hline & $\mathrm{T} 3$ & 1.716 & - \\
\hline
\end{tabular}


BASE SHEAR INX-DIRECTION

\begin{tabular}{|l|l|l|l|}
\hline NO & $\begin{array}{l}\text { MODEL } \\
\text { TYPE }\end{array}$ & Vs(KN) & REDUCTION(\%) \\
\hline 1 & T1 & 4233.45 & 13 \\
\hline 2 & T2 & 4870.29 & 30 \\
\hline 3 & T3 & 6049.09 & - \\
\hline
\end{tabular}

\begin{tabular}{|l|l|l|l|}
\multicolumn{5}{|c}{ Y-DIRECTION } \\
\hline NO & $\begin{array}{l}\text { MODEL } \\
\text { TYPE }\end{array}$ & Vs(KN) & $\begin{array}{l}\text { REDUCTION( } \\
\%\end{array}$ \\
\hline 1 & T1 & 4123.49 & 19 \\
\hline 2 & T2 & 5091.76 & 30.7 \\
\hline 3 & T3 & 5956.99 & - \\
\hline
\end{tabular}

\section{CONCLUSIONS}

\section{RESPONSE SPECTRUM ANALYSIS}

In the present work a 10 storied structure is designed as per IS 456 \& IS1893. It is` observed that the L Shape mivan wall model shows significant reduction in the range of $50 \%$ to $91 \%$ ( in displacements drift ratio) \& base shear in the range of $13 \%$ to $31 \%$.

Thus the work shows that, the performance of L Shape mivan wall building is better among other irregular mivan structures.

\section{REFERENCES}

[1]. Inelastic Earthquake Response Of Buildings Subjected To Torsion ,12WCEE 2000,PP-0781, kyriakos G Stathopoulos And Stavros A Anagnostopoulos,

[2]. Guyader, Important Features Of The Response Of Inelastic Structures To Near-Field Ground Motion, 12WCEE 2000,PP-1740,Wilfred D Iwan, Ching-Tung Huang And Andrew C

[3]. B. Borzi And A. S. Elnashai, Assessment Of Inelastic Response Of Buildings

[4]. Srinivas \& Bharatha, A Study On Inelastic Response Of Multi-Storey Buildings To Near-field Ground Motions, Report no-G22189, Dec-2007. 